\title{
EATING PRACTICE OF SUNDANESE WOMEN IN THE POSTPARTUM PERIOD
}

\author{
Ermiati $^{1}$, Restuning Widiasih ${ }^{1}$, Anita Setyawati ${ }^{1}$ \\ ${ }^{1}$ Faculty of Nursing, Universitas Padjajaran \\ Corresponding email: ermiati@unpad.ac.id
}

\begin{abstract}
Cultural practices are still very strong in Indonesia, but sometimes they are contrary to health. So that often these cultural practices cause pain and even death. Abstinence to eat in Sundanese society is a cultural practice. The purpose of this study was to determine the practice of eating in mothers of postpartum in Sundanese culture. This type of research is a quantitative descriptive. The sample in this study was 25 mothers of postpartum with criteria of Sundanese husband and wife and the mother was still in puerperium for up to 40 days. The research instrument was in the form of a questionnaire about food culture practices, the data were analyzed by the presentation. The results showed that $22(88 \%)$ of postpartum women abstain of eating. Types of restrictions that eating eggs, fish, meat, natural water, fruits, eating soup and eating a lot. There is still abstinence from eating in the postpartum women which can cause late recovery of health in the mother of postpartum, it is expected that the health center provides counseling about the nutritional needs of mothers of postpartum and discusses each type of food that is abstinence food in the community.
\end{abstract}

Keywords: Sundanese Culture, postpartum, practice.

\section{INTRODUCTION}

Based on the 2015 Indonesian Population Demographic Survey (IPDS), the maternal mortality rate (MMR) is still high at 305 per 100,000 live births. This is still far from the target of SDG'S (Sustainable Development Goals) in 2030, which is MMR of 70 / 100,000 KH (Ministry of Health Republic of Indonesia, 2016). Death of mothers in the view of Indonesian society is strongly influenced by cultural practices in the community. Many cultural practices that aim to improve the degree of maternal and fetal health become the cause of morbidity and mortality in the perinatal period for both mother and fetus. Some cultures in the postpartum period include the prohibition of eating fish, eggs and other nutritional foods because it might cause delaying of wounds healing processes and smelly puerperal blood (Syafrudin and Mariam, 2013). In the postpartum period is highly recommended for women to eat rice with salt, cassava leaves, and bungkal leaves. This food does not contain protein that serves to accelerate wound healing even low nutritional intake, this causes late recovery of postpartum health due to malnutrition (Suprabowo, 2006). Implementation and food culture recommendations for postpartum mothers result in a decrease in nutritional intake, which affects the quality and quantity of breast milk that would also affect the risk of nutritional status of the fetus. 
The community health center of Griya Antapani is located in the urban areas of Bandung city that identic with modern lifestyle, however, the cultural practices of the postpartum women still exist in the community. It can be seen from the control visit of post SC women, women said that they did not consume eggs and fish because it can make the wound itchy and slow to recover. Abstinence from eating eggs is also carried out by mothers of normal postpartum, they said that they are afraid of the perineum recovery would delay because of consuming eggs. Some taboos are believed by Sundanese people and there are many cultural issues related to the postpartum women which are still believed to this day, however, limited study assess eating practices in this culture. The purpose of this study was to determine the practice of eating in mothers of postpartum in Sundanese culture

\section{METHODS}

This type of research is a quantitative descriptive of Sundanese cultural practices in the Mother of Postpartum. The sample in this study was 25 postpartum mothers in the work area of the Griya Antapani Bandung PHC, the samples criteria were Sundanese and the mother was in the postpartum condition for up to 40 days. This research instrument was in the form of a questionnaire containing food culture practices, women filled in 10 statements of cultural practices with a choice of "yes" or "no", and data analyzed by frequency presentation and presented in the frequency distribution table.

\section{RESULTS}

Sundanese Culture Practices In Food Matters In the postpartum women

Table 1 Women' Sundanese Culture Practices in the Post Partum period

\begin{tabular}{|c|c|c|}
\hline $\begin{array}{c}\text { Sundanese Food Culture } \\
\text { Practices }\end{array}$ & $\mathbf{f}$ & $\%$ \\
\hline Abstinence & 22 & 88,0 \\
\hline Not & 3 & 12,0 \\
\hline Total & 25 & 100 \\
\hline
\end{tabular}


Based on the results of table 1 it was found that Sundanese Cultural Practices in Food Matters In the postpartum women are mostly in the category of having abstinence, as many as 22 people $(88.0 \%)$.

Table 2 Sundanese Culture Practices in Postpartum

\begin{tabular}{lcccc}
\hline \multirow{2}{*}{ Abstinence of Eating } & \multicolumn{2}{c}{ Yes } & \multicolumn{2}{c}{ Not } \\
\cline { 2 - 5 } & $\mathbf{f}$ & $\%$ & f & $\%$ \\
\hline Eggs, fish, meat & 7 & 28.0 & 18 & 72,0 \\
Natural Water & 10 & 40,0 & 15 & 60,0 \\
Eating soup & 6 & 24,0 & 19 & 76,0 \\
Fruits & 8 & 32,0 & 17 & 68,0 \\
Eating a lot & 16 & 64,0 & 9 & 36,0 \\
\hline
\end{tabular}

Based on table 2 that the results of the study found that abstinence from eating eggs, fish, meat as much as 7 people $(28.0 \%)$, abstinence from natural water as much as 10 people $(40.0 \%)$, eating as much as 6 people $(24.0 \%)$, fruits as many as 8 people $(32.0 \%)$ and abstinence from eating a lot as many as 16 people $(64.0 \%)$.

\section{DISCUSSION}

Based on the results, the study found that most of the mothers of postpartum have dietary restrictions during postpartum. The types of food that are challenged or avoided for consumption are eating eggs, fish, and meat. The belief of respondents that eating eggs, fish and meat will make the wound after giving birth will experience itching and hard to heal. This causes postpartum women do not want to consume these foods.

Eggs, fish, and meat are good nutrition for mothers of postpartum. The protein content contained in eggs, fish, and meat has a high protein content with the most complete amino acids. Eggs, fish, and meat become very good food for the recovery process after labor and accelerate the wound healing process. In postpartum mothers, precisely the fulfillment of protein needs is increasing to help heal wounds in the uterine wall and in the birth canal 
which has stitches. Protein is used as a builder that forms the body's muscle tissue and accelerates wound recovery (Purwoastuti \& Walyani, 2015).

According to Sarwono (2005), avoiding protein foods such as fish and eggs is a common practice in the community of women in the postpartum period which is detrimental to women and their babies. Prohibitions about abstinence from certain foods for postpartum women are a myth. This is indeed difficult to remove because it has become a very trusted and continuously carried out until now. This can be due to the strong socio-cultural influence on daily habits. Customs and traditions regarding abstinence have been carried out by the community for a long time and do not dare to violate because they are afraid of the consequences that will result when violating the culture.

Based on research results, most mothers of postpartum are also prohibited from drinking lots of water and food. This is according to the local belief that mothers of Post Partum should not drink a lot of water or eat food because it will make babies urinate frequently and wounds on women will be wet and wound difficult to heal. Eating foods that are believed to have the uterus will be slippery so that the Shamen will have difficulty when doing the massage to return the position of the uterus to its original position. This abstinence is very dangerous for postpartum women such as dehydration or lack of fluids.

The postpartum women food and drink should meet the body's need, for fluids which are 2.5-3 liters per day, accompanied by milk and fruit juice intake. The benefits of water for health are very many. In the human body consists of more than $70 \%$ of fluids where the need for fluid is very high. The benefits of water in the body certainly cannot be replaced by anything. This liquid can be obtained by consuming enough water. Water is the healthiest and harmless drink because it is needed every day by the body to maintain health (Saleha, 2009).

Vegetable soup is beneficial for postpartum which is to avoid constipation or postpartum constipation, mothers are strongly encouraged to consume fiber-rich foods that are commonly found in Vegetable soup. Enough fiber in food will make the stool soft and slippery so that it easily passes through the intestine, so the mother does not need to strain strongly when defecating so that it can exacerbate the pressure on the stitches in perineum or episiotomy. Pressure from straining when constipation occurs can make the wound hurt or even be opened again. (Marin, 2009).

The results of the study also found that the majority of postpartum mothers abstained from eating fruits. Respondents believe that mothers of postpartum who eat fruits will cause baby diarrhea. According to the shaman's belief that mothers of post-partum who eat lots of fruit will cause the stomach to become swollen and get pregnant quickly again. In addition, 
the myth can make muddy female organs. Abstinence in consuming fruits in postpartum mothers is very detrimental to mothers of postpartum and infants.

The fruit is very good for maintaining physical fitness and in no way adversely affects the baby and the quality of breast milk. Consuming fruit does not cause diarrhea in infants. In addition, the mother of childbirth also requires the intake of fibrous foods such as fruits and vegetables to facilitate defecation. In the postpartum women, fiber needs are very important to help the digestive process, the levels of vitamins and water in fruit are also very good for maintaining a healthy body. For example orange juice, bananas, and papaya. We recommend that the mother of childbirth always include a menu of fruit at every meal so as not to experience constipation.

Postpartum women can get fiber naturally in fruits such as papaya, red guava, orange, pear, mango, kiwi, strawberry, dragon fruit, and other fruits. So it is very wrong if papaya and banana must be avoided after the birth of a mother due to the myth that it can make the female organs can not dry. Instead, bananas and papayas are classified as a source of food that contains lots of fiber to facilitate defecation (BAB). In addition, fruits rich in fiber can reduce bleeding that occurs, because the fruits are proven to help increase platelets to reduce bleeding and form new pieces of blood to prevent bleeding in the uterus or in stitches during childbirth (Marin, 2009).

The results of this study also showed that most mothers of postpartum abstain from eating too much. The postpartum women stated that she has not eaten if she has not eaten rice even though she has consumed other food instead of rice. Pregnant women are forbidden to eat a lot of rice so that the body will quickly slim again like before pregnancy. The notion of what is called food and not food is a social construction. The community thinks that someone eats when they eat rice. Foster \& Anderson (2006) states that people generally believe that the quantity of food is important while quality is limited to strengthen the body and is often ignored. Eating habits are habits that will not change quickly and will be difficult to change if the food has deep meaning.

In postpartum women, nutritious food and food portions need to be improved better than before pregnancy. Sources of carbohydrates, fats, vitamins, and proteins are needed for the process of physical recovery of the mother during childbirth and fight infection. In addition, it is also useful for the smooth formation of breast milk. Slim not with a strict diet after giving birth, but by doing puerperal exercises and exclusively breastfeeding babies without the help of formula milk. In this way, fat burning in the body will take place better and the mother will quickly lean again like before pregnancy (Saleha, 2009). 


\section{CONCLUSION}

Sundanese culture practices in terms of food at the postpartum women mostly shows there are restrictions on food. The types of food that are challenged are eggs, fish, meat, fruits and may not eat and drink a lot. The existence of abstinence eating in Sundanese gives an impact to the community health center to provide counseling about the nutritional needs of mothers of postpartum and discuss any type of food that is abstinence in the community.

\section{REFERENCES}

Foster \& Anderson, (2006). Antropologi Kesehatan.Jakarta: Penerbit Universitas Indonesia.

Kemenkes RI. (2016). Profil Kesehatan Indonesia Tahun 2015. Jakarta : Kemenkes RI.

Marin. (2009). Pantangan dalam makanan dan sayuran untuk ibu hamil dan masa nifas. Jakarta. EGC

Purwoastuti dan Walyani. (2015) . Ilmu Sosial Dan Budaya Dasar Pada Kebidanan Yogyakarta: Pustaka Press

Sarwono. (2005). Ilmu Kebidanan. Jakarta: Yayasan Bina Pustaka

Saleha,S. (2009). Asuhan Kebidanan Pada Masa Nifas. Jakarta: Salemba.

Suprabowo. (2006). Praktik Budaya Dalam Kehamilan Persalinan Dan Nifas. Diakses dari http://jurnalkesmas.ui.ac.id.diunduh pada tanggal 08 februari 2018

Syarifudin dan Maryam. (2013). Sosial Budaya Dasar Untuk Mahasiswa Kebidanan. Jakarta: TIM 